\section{'Kalos', a New Pecan Cultivar for Commercial Orchards in the Southeastern United States}

\author{
Patrick J. Conner \\ University of Georgia-Tifton Campus, 2360 Rainwater Road, Tifton, GA \\ 31793
}

Additional index words. breeding, Carya illinoinensis, cultivar, genetics

'Kalos' is a new pecan (Carya illinoinensis) cultivar released by the University of Georgia College of Agriculture and Environmental Sciences. 'Kalos' produces good yields of large, high-quality pecans. 'Kalos' matures in early October in southern Georgia. Nuts produced by 'Kalos' are easily shelled into complete halves, and the kernels have a light golden color. 'Kalos' has moderate resistance to pecan scab (Venturia effusa), with low levels of disease symptoms in orchards using fungicides to control this disease. 'Kalos' is recommended for planting in the southeastern United States in orchards that will receive fungicide applications.

\section{Origin}

In 2003 the cross 03-6 ('Sioux' $\times$ 'Desirable') was made by Patrick Conner at the University of Georgia Tifton Campus. 'Sioux' is a 1962 U.S. Department of Agriculture release that is notable for its light kernel color, excellent shelling ability, and vigorous growth (Conner and Thompson, 2003; Madden, 1974; McEachern, 1998). 'Sioux' was at one time recommended for planting in Georgia (Goff, 1999), but large plantings were not made because the nut size is too small $(6.2 \mathrm{~g})$ to bring maximum prices (Conner and Thompson, 2003). 'Desirable' was the most planted pecan cultivar in Georgia for several decades (Sparks, 1997). Attractive traits of 'Desirable' are large nut size, consistent bearing, light kernel color, and excellent shelling ability into complete halves. Unfortunately, 'Desirable' has become extremely susceptible to pecan scab disease, caused by the fungus Venturia effusa, and is therefore no longer recommended for planting in southern Georgia, where scab is more prevalent (Wells and Conner, 2015). Cross 03-6 produced 205 nuts from which 124 seedlings were transplanted into a seedling orchard after growing the seedlings in pots for 1 year and removing those with symptoms of pecan scab on the foliage. Seedlings were

Received for publication 8 Nov. 2021. Accepted for publication 1 Dec. 2021.

Published online 25 January 2022.

P.J.C. is the corresponding author. E-mail: pconner@ uga.edu.

This is an open access article distributed under the CC BY-NC-ND license (https://creativecommons. org/licenses/by-nc-nd/4.0/). transplanted into the seedling orchard in 2005 on the Tifton Campus. 'Kalos' was tested as Ga 03-6-32 and first fruited in 2008, when it was selected for its large size (46 nuts/lb) and high kernel percentage $(60 \%)$. 'Kalos' was propagated for yield trials in 2009.

\section{Methods}

The first yield testing location was in Tift County, GA, on an experimental farm (lat. $31^{\circ} 30^{\prime} 34.74^{\prime \prime} \mathrm{N}$, long. $\left.83^{\circ} 38^{\prime} 25.91^{\prime \prime} \mathrm{W}\right)$. To accelerate the testing of new selections, 'Kalos' and 'Avalon' were topworked into an existing yield trial of other cultivars that was planted at this location in 2005. Topworked trees for 'Kalos' consisted of single trees of 'Newt', 'Carter', U.S. Department of Agriculture 82-17-680, and 'Leger-1'. Trees for the yield trial were planted into a single orchard block with a tree spacing of $12.2 \times$ $12.2 \mathrm{~m}$ (67 trees/ha), and a completely randomized cultivar location and three to six replications for each cultivar (Table 1). Nitrogen was applied annually at $112 \mathrm{~kg} \cdot \mathrm{ha}^{-1}$, whereas other nutrients and lime were applied according to leaf or soil analysis. Microsprinkler irrigation was used with one $76-\mathrm{L} \cdot \mathrm{h}^{-1}$ microsprinkler per tree. Fungicides and insecticides were applied according to Georgia Extension Service recommendations (Hudson et al., 2006).

In 2009, 'Kalos' and 'Avalon' trees were topworked into the Tift County trial by cutting off the branches of the original trees and placing bark grafts onto four or five major branches. Because 'Kalos' and 'Avalon' trees were topworked into this trial, it was not

Table 1 . Alternate bearing intensity $(I)$, phenology, and nut and kernel quality attributes of pecan cultivars in Tift County, GA, in the 7th through 15th year of growth (2012-20).

\begin{tabular}{lccccccc}
\hline Cultivar & $\begin{array}{c}\text { Trees } \\
\text { (no.) }\end{array}$ & $I^{\mathrm{z}}$ & $\begin{array}{c}\text { Nuts per } \\
\text { cluster (no.) }\end{array}$ & $\begin{array}{c}\text { Nut } \\
\text { wt }(\mathrm{g})\end{array}$ & $\begin{array}{c}\text { Kernel } \\
(\%)\end{array}$ & $\begin{array}{c}\text { Avg day of } \\
\text { bud burst }\end{array}$ & $\begin{array}{c}\text { Avg day of 50\% } \\
\text { shuck split }\end{array}$ \\
\hline Kalos $^{\mathrm{x}}$ & 4 & $0.28 \mathrm{~b}^{\mathrm{w}}$ & $2.3 \mathrm{~b}$ & $10.0 \mathrm{c}$ & $55.3 \mathrm{a}$ & 2 Apr. ab & 4 Oct. b \\
Avalon $^{\mathrm{x}}$ & 6 & $0.18 \mathrm{bc}$ & $2.5 \mathrm{~b}$ & $9.6 \mathrm{bc}$ & $53.5 \mathrm{~b}$ & 4 Apr. a & 2 Oct. b \\
Byrd & 4 & $0.39 \mathrm{a}$ & $3.2 \mathrm{a}$ & $9.0 \mathrm{a}$ & $56.0 \mathrm{a}$ & 24 Mar. c & 18 Sept. c \\
Desirable & 4 & $0.14 \mathrm{c}$ & $2.2 \mathrm{~b}$ & $9.9 \mathrm{c}$ & $48.2 \mathrm{~d}$ & 31 Mar. b & 7 Oct. ab \\
Gafford & 4 & $0.22 \mathrm{bc}$ & $2.5 \mathrm{~b}$ & $9.2 \mathrm{ab}$ & $50.0 \mathrm{c}$ & 4 Apr. a & 11 Oct. a \\
Pawnee & 3 & $0.45 \mathrm{a}$ & $3.2 \mathrm{a}$ & $9.5 \mathrm{~b}$ & $55.8 \mathrm{a}$ & 13 Mar. b & 10 Sept. d \\
Significance & - & $<0.001$ & $<0.001$ & $<0.001$ & $<0.001$ & $<0.001$ & $<0.001$ \\
\hline
\end{tabular}

${ }^{\mathrm{z}}$ Alternate bearing intensity: $1=$ complete alternation, $0=$ identical yields each year.

${ }^{\mathrm{y}} \mathrm{Bud}$ burst is defined as the stage of growth when individual leaflets separate from the expanding bud.

'Kalos' and 'Avalon' were topworked into the orchard in 2009 and in 2012 their yields were similar to year 7 yields of non-topworked trees they were considered to be 7 years old.

${ }^{\text {w}}$ Mean separation within a column by Duncan's multiple range test, $P \leq 0.05$.

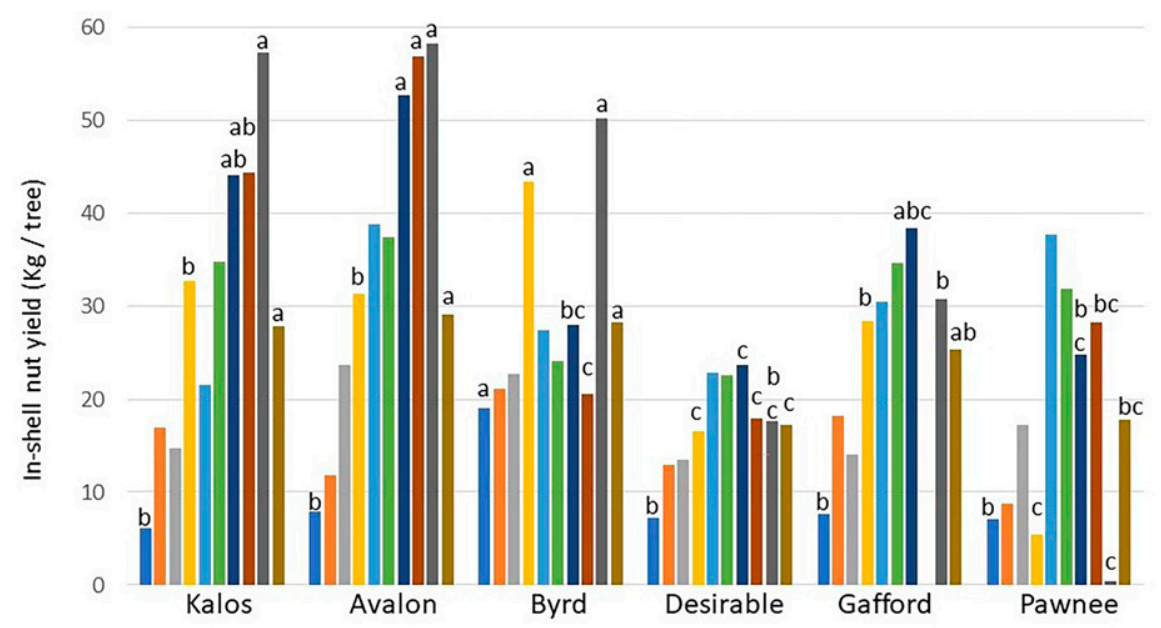

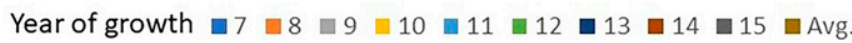

Fig. 1. Average annual in-shell nut yield (kilograms per tree) of pecan cultivars in Tift County, GA, in the 7th through 15th year of growth (2012-20). Mean separation within a year of growth by Duncan's multiple range test, $P \leq 0.05$. 'Gafford' year 14 yield was lost to Hurricane Michael. 
Table 2. Average quality and pest resistance of pecan cultivars in a sprayed orchard in Berrien County, GA, in the sixth through ninth year of growth (2017-20).

\begin{tabular}{|c|c|c|c|c|c|c|c|}
\hline Cultivar & $\begin{array}{l}\text { Trees } \\
\text { (no.) }\end{array}$ & $\begin{array}{c}\text { Nut } \\
\text { wt (g) }\end{array}$ & $\begin{array}{c}\text { Kernel } \\
(\%)\end{array}$ & $\begin{array}{l}\text { Leaf scab } \\
(1-4 \text { scale })^{z}\end{array}$ & $\begin{array}{l}\text { Avg nut scab } \\
(1-5 \text { scale })^{\mathrm{y}}\end{array}$ & $\begin{array}{l}\text { Max. nut scab } \\
(1-5 \text { scale })^{x}\end{array}$ & $\begin{array}{l}\text { Black pecan } \\
\text { aphid damage } \\
(1-4 \text { scale })^{\mathrm{w}}\end{array}$ \\
\hline$\overline{\text { Kalos }}$ & 4 & $9.7 b^{v}$ & $57.2 \mathrm{a}$ & $1.0 \mathrm{~b}$ & $1.0 \mathrm{~b}$ & $1.0 \mathrm{c}$ & $1.0 \mathrm{~b}$ \\
\hline Avalon & 3 & $9.0 \mathrm{a}$ & $53.6 \mathrm{~b}$ & $1.0 \mathrm{~b}$ & $1.0 \mathrm{~b}$ & $1.0 \mathrm{c}$ & $1.9 \mathrm{a}$ \\
\hline Desirable & 4 & $10.2 \mathrm{~b}$ & $48.9 \mathrm{c}$ & $1.8 \mathrm{a}$ & $2.7 \mathrm{a}$ & $3.4 \mathrm{a}$ & $1.0 \mathrm{~b}$ \\
\hline Zinner & 4 & $9.9 \mathrm{~b}$ & $56.2 \mathrm{a}$ & $1.0 \mathrm{~b}$ & $1.4 \mathrm{~b}$ & $2.1 \mathrm{~b}$ & $1.6 \mathrm{a}$ \\
\hline Significance & - & $<0.001$ & $<0.001$ & 0.01 & $<0.001$ & $<0.001$ & $<0.001$ \\
\hline
\end{tabular}

${ }^{\mathrm{z}_{1}}=$ no scab lesions, $2=$ a few isolated lesions with restricted growth, $3=$ multiple lesions with expanding growth, $4=$ stem scab lesions or defoliation.

${ }^{\mathrm{y}_{1}}=$ no scab lesions; $2=$ a few lesions with restricted growth; $3=$ multiple lesions, $0 \%$ to $10 \%$ coverage; $4=11 \%$ to $50 \%$ coverage; $5=51 \%$ to $100 \%$ coverage or nut drop. Average damage seen on nuts over the tree.

${ }^{\mathrm{x}} 1=$ no scab lesions; $2=$ a few lesions with restricted growth; $3=$ multiple lesions, $0 \%$ to $10 \%$ coverage; $4=11 \%$ to $50 \%$ coverage; $5=51 \%$ to $100 \%$ coverage or nut drop. Maximum damage seen on any nut.

${ }^{\mathrm{w}_{1}} 1=$ no damage; $2=$ light chlorotic spotting, $0 \%$ to $25 \%$ leaves affected; $3=$ moderate chlorotic spotting, $26 \%$ to $75 \%$ chlorotic spotting; 4 = heavy chlorotic spotting, $76 \%$ to $100 \%$ leaves affected. ${ }^{\mathrm{v}}$ Mean separation within a column by Duncan's multiple range test, $P \leq 0.05$.

possible to compare their yield directly to the other cultivars based on year from planting. However, yield from topworked trees was similar to 7-year-old non-topworked trees in 2012 (Fig. 1), and 'Avalon' yields were compared with non-topworked trees from that point forward. Annual yield fluctuation was expressed as alternate bearing intensity $(I)$, a measure of intensity of deviation in yield in successive years (Pearce and DobersekUrbanc, 1967): $I=1 /(n-1) \times\left[\mid\left(a_{2}-a_{1}\right) / /\left(a_{2}\right.\right.$ $\left.+a_{1}\right)+\left|\left(a_{3}-a_{2}\right)\right| /\left(a_{3}+a_{2}\right) \ldots+\mid\left(a_{(n)}-\right.$ $a_{(n-1)} / /\left(a_{(n)}+a_{(n-1)}\right]$, where $n$ is the number of years and $a_{1}, a_{2}, \ldots, a_{(n-1)}, a_{n}$ is the yield of corresponding years. $I$ varies from a maximum of 1 which indicates a yield of 0 every other year, to a minimum of 0 , indicating identical yields each year.

A second yield trial was planted in 2012 in a commercial pecan orchard in Berrien County, GA (lat. $31^{\circ} 2^{\prime} 7.09^{\prime \prime} \mathrm{N}$, long. $83^{\circ} 15^{\prime} 9.49^{\prime \prime} \mathrm{W}$ ). Trees were spaced 7.6 and $15.2 \mathrm{~m}$ within and between rows, respectively, with three to four replications for each cultivar (Table 2). All lime and fertilizer were applied according to leaf and soil analysis recommendations using Georgia Extension Service recommendations as a guide (Hudson et al., 2006). Microsprinkler irrigation was used with one $75.7-\mathrm{L} \cdot \mathrm{h}^{-1}$ microsprinkler per tree. Fungicides and insecticides were applied according to Georgia Extension Service recommendations (Hudson et al., 2006). I was not measured in this trial because of an insufficient number of years of evaluation.

A random 50-nut sample was taken from each tree annually to determine nut quality. Nuts were shelled and the of percentage edible kernel was calculated by weight. Nuts were harvested when more than $90 \%$ could be shaken from the tree with a mechanical shaker. Phenology data were recorded only for the trees located at Tift County. Trees were monitored in the spring for budbreak phenology by evaluating twice weekly for the presence of extended individual leaflets in the exterior lower canopy, the presence of which was used to indicate budbreak. Dichogamy type and flowering period were determined by observing trees twice weekly in April and May. The pollen shed period was evaluated by tapping catkins and looking for the presence of shedding pollen. The beginning of stigma receptivity was indicated by swollen stigmatic papillae and the presence of secretions on the stigmatic surface (Wetzstein and Sparks, 1989), giving the stigma a waxy look. The end of receptivity was determined by the presence of dry, brown stigmas. Beginning in mid-September, trees were monitored twice weekly for shuck split by recording the percentage of 20 nuts observed around the tree canopy with dehisced shuck sutures. Leaf scab, nut scab, and black pecan aphid (Melanocallis caryaefoliae) damage were evaluated in September of each year. Leaf scab was evaluated on a scale of 1 to 4 , with the worst disease expression recorded, where $1=$ no scab lesions, $2=$ a few isolated lesions with restricted growth, $3=$ multiple

60

50

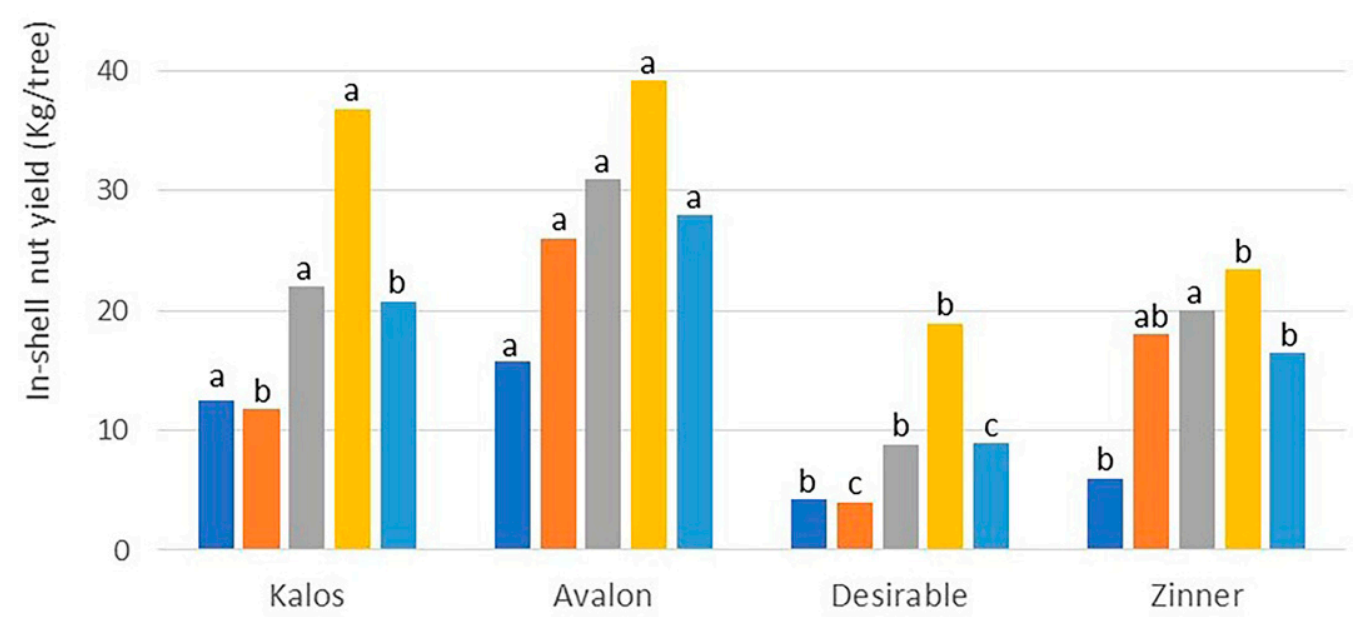

Year of growth $\square 6 \square 7 \square 8 \square 9 \square$ Avg.

Fig. 2. Average annual in-shell nut yield (kilograms per tree) of pecan cultivars in Berrien County, GA, in the sixth through ninth year of growth (2017-20). Mean separation within a year of growth by Duncan's multiple range test, $P \leq 0.05$. 


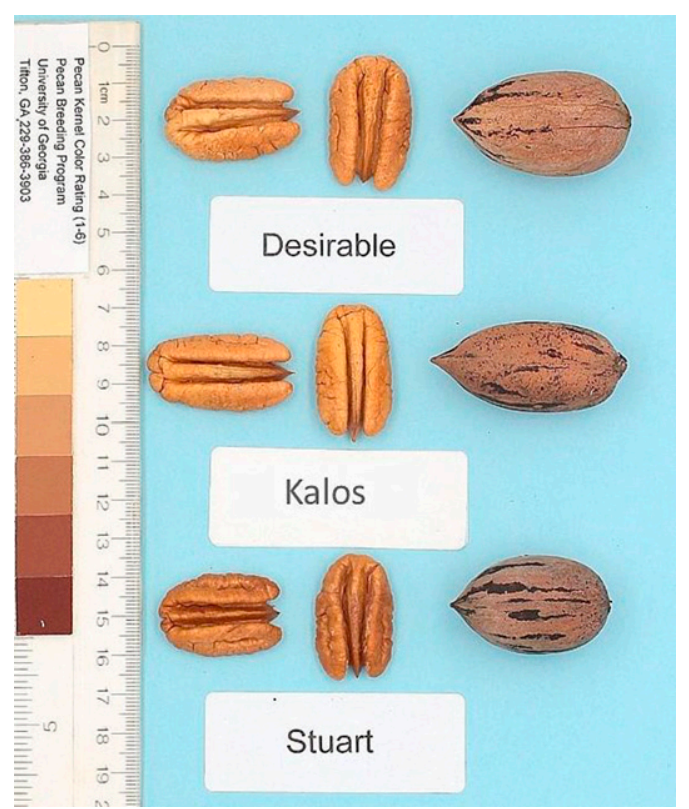

Fig. 3. 'Kalos' nut and kernel attributes in comparison with 'Desirable' and 'Stuart'.

lesions with expanding growth, and $4=$ stem scab lesions or defoliation. Nut scab was evaluated on a 1-to- 5 scale, with the average and worst disease expression recorded, where $1=$ no scab lesions; $2=$ a few lesions with restricted growth; 3 = multiple lesions, with
$0 \%$ to $10 \%$ coverage; $4=11 \%$ to $50 \%$ coverage; and $5=51 \%$ to $100 \%$ coverage or nut drop. Black pecan aphid damage was rated on a 4-point scale by observing the lower interior canopy: $1=$ no damage; $2=$ light chlorotic spotting; $0 \%$ to $25 \%$ leaves affected; $3=$ moderate chlorotic spotting, $26 \%$ to $75 \%$ leaves affected; and $4=$ heavy chlorotic spotting, $76 \%$ to $100 \%$ leaves affected.

In addition to the two yield trials, a minimally sprayed scab resistance trial of multiple cultivars was maintained at a nearby orchard on the Tift County farm. This orchard received similar care to the yield trials except that only two sprays are applied in August to control hickory shuckworm (Cydia caryan) and pecan scab is left untreated. One to three trees of various cultivars and selections were grafted in a single block randomized design into this trial to observe scab infection levels on untreated trees in a high-disease pressure situation using the methods described previously. Nut yield and quality data were not obtained from this orchard.

Yields for each year of growth were calculated for each clone by averaging all the replicate trees for that clone for the given year. Quality and pest resistance characteristics in the yield trials were calculated by averaging

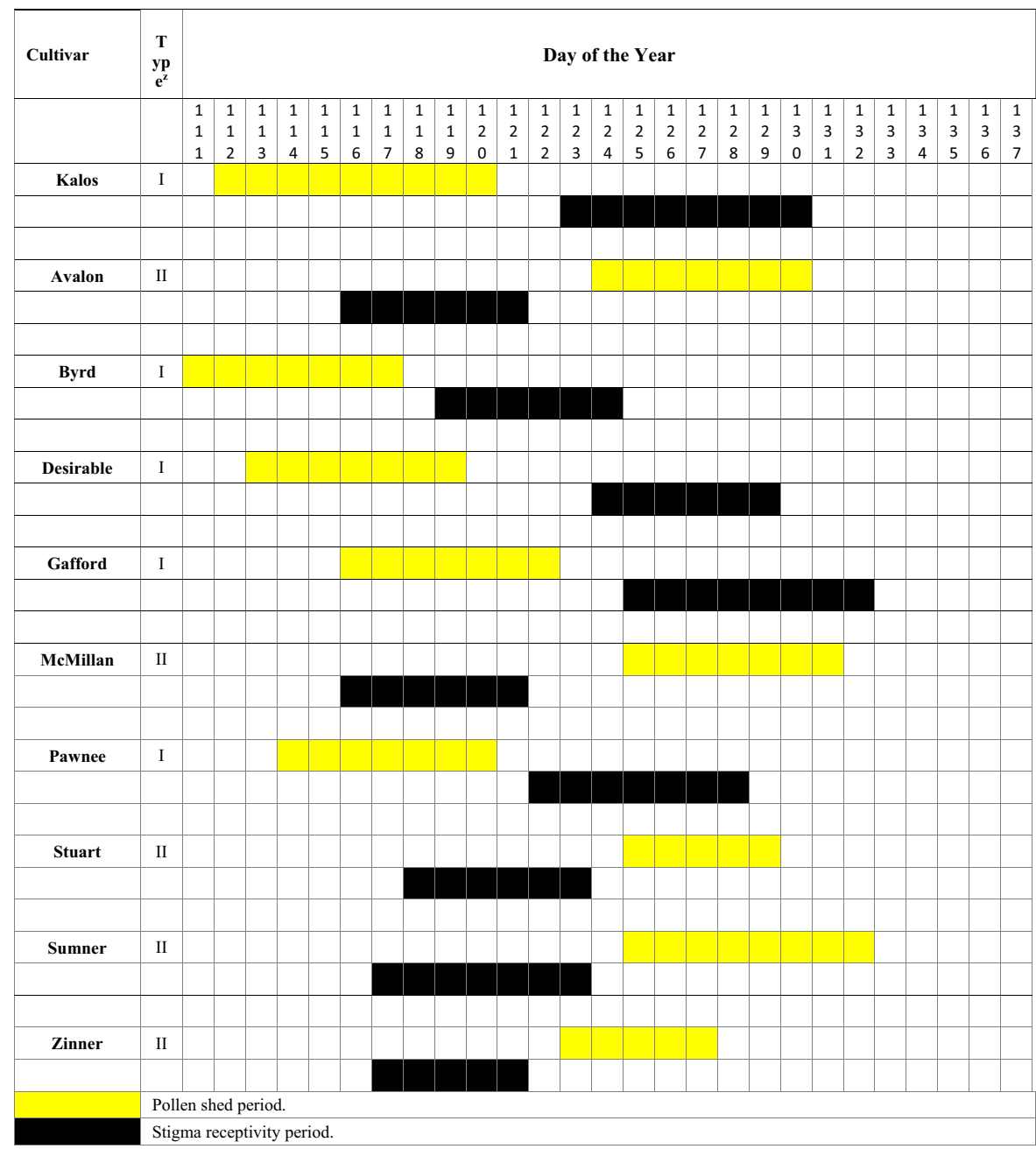

${ }^{\mathrm{z}}$ Type I = protandrous, Type II = protogynous.

Fig. 4. Average pollen shed and pistil receptivity for 'Kalos' and common pecan cultivars in Tift County, GA. 
Table 3. Pest resistance of pecan cultivars in a sprayed orchard in Tift County, GA, in the 7th through 15th year of growth (2012-20).

\begin{tabular}{|c|c|c|c|c|c|}
\hline Cultivar & Trees (no.) & Leaf scab $(1-4 \text { scale })^{z}$ & Avg nut scab $(1-5 \text { scale })^{y}$ & Max. nut scab $(1-5 \text { scale })^{\mathrm{x}}$ & Black pecan aphid damage $(1-4 \text { scale })^{\mathrm{w}}$ \\
\hline$\overline{\text { Kalos }^{v}}$ & 4 & $1.2 \mathrm{~b}^{\mathrm{u}}$ & $1.0 \mathrm{~d}$ & $1.5 \mathrm{~d}$ & $1.1 \mathrm{c}$ \\
\hline Byrd & 4 & $1.2 \mathrm{~b}$ & $2.4 \mathrm{~b}$ & $3.8 \mathrm{~b}$ & $1.3 \mathrm{bc}$ \\
\hline Desirable & 4 & $2.9 \mathrm{a}$ & $3.7 \mathrm{a}$ & $4.8 \mathrm{a}$ & $1.3 \mathrm{bc}$ \\
\hline Pawnee & 3 & $1.1 \mathrm{~b}$ & $1.6 \mathrm{c}$ & $3.0 \mathrm{c}$ & $1.5 \mathrm{~b}$ \\
\hline Significance & - & $<0.001$ & $<0.001$ & $<0.001$ & $<0.001$ \\
\hline
\end{tabular}

${ }^{\mathrm{z}} 1=$ no scab lesions, 2 = a few isolated lesions with restricted growth, $3=$ multiple lesions with expanding growth, $4=$ stem scab lesions or defoliation.

${ }^{y_{1}} 1=$ no scab lesions; $2=$ a few lesions with restricted growth; $3=$ multiple lesions, $0 \%$ to $10 \%$ coverage; $4=11 \%$ to $50 \%$ coverage; $5=51 \%$ to $100 \%$ coverage or nut drop. Average damage seen on nuts over the tree.

${ }^{\mathrm{x}} 1=$ no scab lesions; $2=$ a few lesions with restricted growth; $3=$ multiple lesions, $0 \%$ to $10 \%$ coverage; $4=11 \%$ to $50 \%$ coverage; $5=51 \%$ to $100 \%$ coverage or nut drop. Maximum damage seen on any nut.

${ }^{\mathrm{w}_{1}} 1=$ no damage; 2 = light chlorotic spotting, $0 \%$ to $25 \%$ leaves affected; $3=$ moderate chlorotic spotting, $26 \%$ to $75 \%$ chlorotic spotting; $4=$ heavy chlorotic spotting, $76 \%$ to $100 \%$ leaves affected.

'Kalos' and 'Avalon' were topworked into the orchard in 2009 and in 2012 their yields were similar to year 7 yields of non-topworked trees they were considered to be 7 years old.

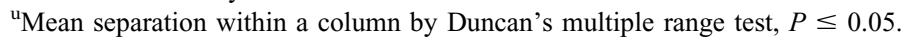

all years of data together. Differences between cultivars were determined using one-way analysis of variance, with mean separation by Duncan's multiple range test $(P<0.05)$. Pest resistance ratings in the scab resistance trial were evaluated in 2013 to 2020 , and years were treated as replications for each cultivar. Statistical analysis was performed using SigmaPlot 12.3 statistical software (Systat Software, San Jose, CA).

\section{Description and Performance}

Yields of topworked 'Kalos' and 'Avalon' that were topworked in 2009 onto 4-year-old rootstocks in the Tift County yield trial were 6 and $8 \mathrm{~kg}$, respectively, in 2012. This yield was similar to three of the four non-topworked cultivars that were in their seventh year of growth that year (Fig. 1). From that point forward, yields of 'Kalos' generally increased, but some irregular bearing was evident, and offyears were seen in years 9 and 11 (Fig. 1). I of 'Kalos' was greater than 'Desirable', but less than highly alternating cultivars such as 'Byrd' and 'Pawnee' (Table 1). The number of nuts per cluster was similar to 'Desirable', and less than 'Byrd' and 'Pawnee'. A paramount attribute of 'Desirable' is the ability of the cultivar to thin the number of nuts per cluster to two to three nuts, reducing the need for crop load thinning treatments and increasing regular bearing (Sparks, 1997). The moderate number of nuts per cluster and relatively low $I$ in 'Kalos' suggest 'Kalos' will have a reduced need for crop thinning to maintain regular bearing. Yields of grafted trees of 'Kalos' in the Berrien County trial were less than 'Avalon', but much greater than the standard cultivar Desirable, and similar to 'Zinner' (Fig. 2). Overall, yields of 'Kalos' were similar to other recommended cultivars such as Zinner and Pawnee, and better than Desirable, suggesting that Kalos will be a productive pecan cultivar in Georgia.

'Kalos' produced a large nut of good quality (Tables 1 and 2, Fig. 3). Nut shape is oblong with a round cross section, an obtuse base, and an acuminate apex (Fig. 3). Striping is common throughout the length of the nut.
The dorsal grooves are moderately wide and generally remain free from packing tissue. The nut shells easily and produces intact kernel halves. Nut size was $10.0 \mathrm{~g}$, with $55.3 \%$ kernel in the Tift County trial (Table 1); and $9.7 \mathrm{~g}$, with $57.2 \%$ kernel in the Berrien County trial (Table 2). The nuts were larger than 'Gafford', 'Byrd', and 'Pawnee', and had a greater kernel percentage than 'Avalon', 'Desirable', and 'Gafford' (Tables 1 and 2). Kernel color is cream to light golden, with no veining or spotting (Fig. 3).

Time of spring budbreak is later than 'Byrd' and 'Pawnee', and similar to the other cultivars trialed (Table 1). 'Kalos' budbreak is late enough to avoid most spring frosts in Georgia. 'Kalos' is protandrous with moderately early pollen shed and mid to mid-late receptivity (Fig. 4). 'Avalon', 'McMillan', 'Stuart', 'Sumner', and 'Zinner' are suitable pollinizers for 'Kalos'. Time of $50 \%$ shuck split in Tift County is in the first week of October and about $3 \mathrm{~d}$ earlier than 'Desirable' (Table 2), giving 'Kalos' an early midseason harvest date. Early harvest date and excellent

Table 4. Pest resistance of pecan cultivars in a minimally sprayed orchard in Tift County, GA (2013-20).

\begin{tabular}{|c|c|c|c|c|c|}
\hline Cultivar & Trees (no.) & Leaf scab $(1-4 \text { scale })^{z}$ & Avg nut scab $(1-5 \text { scale })^{\mathrm{y}}$ & Max. nut scab $(1-5 \text { scale })^{x}$ & Black pecan aphid damage $(1-4 \text { scale })^{\mathrm{w}}$ \\
\hline$\overline{\text { Kalos }}$ & 2 & $1.9 \mathrm{c}^{\mathrm{v}}$ & $2.9 \mathrm{c}$ & $3.8 \mathrm{~b}$ & $1.5 \mathrm{~d}$ \\
\hline Cunard & 1 & $3.2 \mathrm{ab}$ & $4.8 \mathrm{ab}$ & $5.0 \mathrm{a}$ & $1.8 \mathrm{bcd}$ \\
\hline Elliott & 1 & $1.0 \mathrm{c}$ & $1.0 \mathrm{e}$ & $1.0 \mathrm{c}$ & $1.6 \mathrm{~cd}$ \\
\hline McMillan & 1 & $1.0 \mathrm{c}$ & $1.0 \mathrm{e}$ & $1.2 \mathrm{c}$ & $1.7 \mathrm{~cd}$ \\
\hline Pawnee & 1 & $2.1 \mathrm{bc}$ & $4.8 \mathrm{ab}$ & $4.9 \mathrm{a}$ & $2.0 \mathrm{bcd}$ \\
\hline Stuart & 1 & $2.1 \mathrm{bc}$ & $4.6 \mathrm{ab}$ & $5.0 \mathrm{a}$ & $3.1 \mathrm{a}$ \\
\hline Significance & - & $<0.001$ & $<0.001$ & $<0.001$ & $<0.001$ \\
\hline
\end{tabular}

$\mathrm{z}_{1}=$ no scab lesions, 2 = a few isolated lesions with restricted growth, $3=$ multiple lesions with expanding growth, $4=$ stem scab lesions or defoliation.

${ }^{y_{1}}=$ no scab lesions; $2=$ a few lesions with restricted growth; $3=$ multiple lesions, $0 \%$ to $10 \%$ coverage; $4=11 \%$ to $50 \%$ coverage; $5=51 \%$ to $100 \%$ coverage or nut drop. Average damage seen on nuts over the tree.

${ }^{\mathrm{x}} 1=$ no scab lesions; $2=$ a few lesions with restricted growth; $3=$ multiple lesions, $0 \%$ to $10 \%$ coverage; $4=11 \%$ to $50 \%$ coverage; $5=51 \%$ to $100 \%$ coverage or nut drop. Maximum damage seen on any nut.

${ }^{\mathrm{w}_{1}} 1=$ no damage; $2=$ light chlorotic spotting, $0 \%$ to $25 \%$ leaves affected; $3=$ moderate chlorotic spotting, $26 \%$ to $75 \%$ chlorotic spotting; $4=$ heavy chlorotic spotting, $76 \%$ to $100 \%$ leaves affected.

${ }^{\mathrm{v}}$ Mean separation within a column by Duncan's multiple range test, $P \leq 0.05$, with years treated as replications. 
nut size and quality attributes suggest 'Kalos' nuts will receive prices that would be competitive with the best pecan cultivars.

'Kalos' is moderately resistant to pecan scab, with little infection seen in the sprayed orchards at Tift County (Table 3 ) and none in Berrien County (Table 2). However, in the minimally sprayed trial in Tift County, moderately high levels of scab infection were seen (Table 4). Scab resistance was not as good as the recent resistant release 'Avalon', but was better than the currently recommended cultivar Zinner, and much better than the popular scab-susceptible cultivars Desirable and Pawnee. Overall resistance levels were similar to the moderately scab-resistant cultivar Sumner in the minimally sprayed trial (Table 4), indicating scab is controlled easily with standard fungicide applications. The damage from black pecan aphid was among the lowest cultivars in Tift County (Tables 3 and 4) and Berrien County (Table 2).

\section{Availability}

'Kalos' will be a patented cultivar (U.S. plant patent applied for) and is owned by the University of Georgia Research Foundation. Propagation rights are controlled by the University of Georgia Research Foundation, Technology Commercialization Office, Terrell Hall, Athens, GA 30602-7411 (www.ovpr. uga.edu/tco/). A list of nurseries licensed to propagate 'Kalos' pecan can be obtained by contacting the author.

\section{Literature Cited}

Conner, P. and T. Thompson. 2003. Performance of nine pecan cultivars and selections in southern Georgia. J. Amer. Pomol. Soc. 57:115-120.
Goff, B. 1999. Two USDA cultivars that should be planted more in the Southeast. Pecan South 32(11):4.

Hudson, W., J. Brock, S. Culpepper, and L. Wells. 2006. Georgia pecan pest management guide. Univ. of Georgia College of Agr. Bul. 841.

Madden, G. 1974. USDA develops 14 main varieties. Pecan Quart. 8:5-10.

McEachern, G. 1998. 'Sioux' for central Texas. Pecan South 30(12):7-8.

Pearce, S. and S. Dobersek-Urbanc. 1967. The measurement of irregularity in growth and cropping. J. Hort. Sci. 42:295-305.

Sparks, D. 1997. 'Desirable' pecan. Fruit Var. J. 51:2-7.

Wells, L. and P. Conner. 2015. Pecan varieties for Georgia orchards. Univ. of Ga. Coop. Ext. Circ. 898.

Wetzstein, H. and S. Sparks. 1989. Stigma-pollen interactions in pecan. J. Amer. Soc. Hort. Sci. 114:355-359. 